\title{
Biophysical Reviews' national biophysical society partnership program
}

\author{
Damien Hall ${ }^{1,2,3}$
}

Received: 6 March 2020 / Accepted: 6 March 2020 / Published online: 29 April 2020

(C) This is a U.S. government work and not under copyright protection in the U.S.; foreign copyright protection may apply 2020

\begin{abstract}
This Special Issue is focused on the Biophysical Society of Japan. It represents the first in a series tasked with introducing an individual national biophysical society to the wider biophysical community. In this Editorial for Volume 12 Issue 2, I first outline the nature and goals of this program before going on to describe the contents of the Special Issue that relate to the activities organized by the Biophysical Society of Japan and the scope of the research performed by its members.
\end{abstract}

The principal role of Biophysical Reviews is the publication of high-quality topical review articles by experts in the field. However, due to its association with IUPAB (see note), this journal also has a fundamental interest in helping to foster international development and collaboration in the general field of biophysical research. As a practical way of combining these two goals, the journal has initiated (with this Issue) a partnership program with various national biophysical societies aimed at presenting the work of these societies on a world stage. In this first such national society-focused effort, I would like to sincerely thank the Special Issue editors (Komatsuzaki et al. 2020) and the members of the Biophysical Society of Japan (BSJ) for their wholehearted support and participation with this endeavor. In this Editorial, I first describe the goals of this partnership program in general, before exploring the contents of this Special Issue focused on the BSJ in the particular.

Biophysical Reviews is the official publishing instrument of IUPAB (International Union for Pure and Applied Biophysics (IUPAB 2020)). In turn IUPAB is the biophysics affiliate of the ISC (International Science Council (ISC 2020))

Damien Hall

damien.hall@nih.gov; damien.hall@protein.osaka-u.ac.jp;

damienhal130@gmail.com; hall.damien@nitech.ac.jp

1 Laboratory of Biochemistry and Genetics, NIDDK, NIH, Bld. 8, Bethesda, MD 20892-0830, USA

2 Institute for Protein Research, Osaka University, 3-1-Yamadaoka, Suita, Osaka 565-0871, Japan

3 Present address: Department of Life Science and Applied Chemistry, Nagoya Institute of Technology, Nagoya, Japan

\section{National society partnership program}

At their best, national biophysical societies act as important resources for their affiliated members through their activities in organizing national meetings, advocating for research funding, and fostering training and education initiatives. National societies can also provide an important social framework in support of members, constituting a forum for recognizing individual contributions made at various career stages. Each national society is shaped by the unique research strengths and personal characteristics of its membership. Cultivation of new members is vital for building a selfperpetuating organization. With each new generation building on the progress made by the last, the institutional age of the society can often reflect the sophistication of the instruments developed by the society on behalf of their membership. A national language (other than the current common scientific tongue of English) can also play a role in influencing how a society develops and the strategies it employs for successful interfacing with the international community. For these reasons, each national group is unique in terms of the research they specialize in and the manner in which they collectively organize their scientific societies. Although these differences make for an interesting story in themselves, achieving an understanding of these differences can provide the reader with real insight (and possibly empathy) into the challenges faced, and progress made, by others pursuing their scientific endeavor. In this spirit, the major goal of this national biophysical society program series is threefold:

(i) Facilitate international collaboration by making the biophysical societies of particular countries both more familiar and more accessible to the international readership of the journal, with the hope that such information may effectively lessen 
barriers impeding successful interaction between different research groups.

(ii) Provide a platform for promoting and advertising both the activities of the national biophysical society and the research performed by its members, thereby allowing this Special Issue program to collectively showcase the work of a national biophysical society.

(iii) Provide both incentive and instruction to other societies that may be in the process of just forming, or operating soon after establishment. In this role, the journal may be particularly helpful by offering its assistance to the society in organizing and structuring their Special Issue and, further to this, provide a low-cost mechanism for generating quality publications for its members.

In working with a national biophysical society to achieve these goals, Biophysical Reviews can bring some rather large organizational guns to bear. First within its formidable armamentarium is the reputation and resources of the journal. Due to its association with both IUPAB and the Springer Nature group, Biophysical Reviews has arguably the finest academic pedigree and professional resources available to any specialist biophysics-related journal (including an expert support staff). The journal is Q1-ranked within the biophysics category (Scimago 2019). Biophysical Reviews has risen in the Elsevier SCImago rankings, moving from $40^{\text {th }}$ to $13^{\text {th }}$ in class from 2017 to 2018 (with the 2019 results soon to be released) and credited by the same group with an effective impact factor of over 4 .

The second advantage provided by the journal is its equitable costing structure. In my working life as a scientist, I have often been asked to contribute to a themed Special Issue only to later find myself lumped with a non-negotiable obligatory two to four thousand Euro page charge fee. As a joint initiative between nonprofit (IUPAB) and commercial (Springer Nature) organizations, Biophysical Reviews operates on a hybrid open access fee model (Hall 2019). In this system, authors may elect to proceed with either a zero cost option (in which case their article appears behind a paywall for 6 to 12 months $^{1}$ ) or alternatively pay an open access fee allowing their article to be freely downloaded by readers anywhere in the world. This hybrid fee costing system makes a joint ventureship with Biophysical Reviews a genuine partnership in which the national society is not in any danger of being financially exploited by the journal. ${ }^{2}$

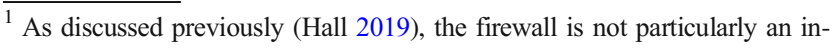
convenience for most due to most major academic institutions carrying the Springer publication package (for instance, all institutions in Germany) the journal being carried within PubMed Central and the fact that every article is issued a free sharing license through the SharedIt ${ }^{\mathrm{TM}}$ program (Hall, 2017).

${ }^{2}$ Indeed the principal benefit to the journal is that it allows it to fulfill its mandated role of helping to promote biophysical research around the world.
}

The third (and possibly most important) force-multiplying resource offered by the journal is the exceptional scientific and personal caliber of the Biophysical Reviews Editorial Board Members. The scientists constituting this group are accomplished experts in their field as well as being conscientious research citizens willing to assist authors to maximize the quality and usefulness of their submitted review. In practice, this pairing of attributes means that review articles submitted to Biophysical Reviews benefit from both high-level reviewing and practical assistance in structuring, framing, and expression (when required) that goes above and beyond that experienced when submitting one's work to a different journal. A general idea of the rara avis nature of the Biophysical Reviews editorial team can be gotten from the recently established "Meet the Editors Series" (Olson 2020; Nagayama 2020).

\section{Exploring biophysics in Japan}

The Biophysical Society of Japan (BSJ) is the first national body to participate in the journal's partnership program. This Special Issue (SI) began with a meeting in August between officers of the Biophysical Reviews journal and a select committee from the BSJ that included the BSJ President, Prof. Yoshie Harada. Members at that meeting decided upon the scope of the SI and created a plan of action for its production. Six SI Editors were nominated, Prof. Tamiki Komatsuzaki (SI lead editor and current BSJ vice president), Prof. Takeharu Nagai (2019 BSJ Annual Meeting Conference chair), Assist. Prof. Saeko Yanaka (winner of the 2016 Inoue Research Award for Young Scientists), Prof. Jeremy Tame (Biophysical Reviews Editorial Board Member), Prof. Haruki Nakamura (former BSJ president, former Biophysical Reviews Executive Editor, and current Chief Editor of the BSJ journal Biophysics and Physicobiology), and Prof. Kuniaki Nagayama (current Biophysical Reviews Executive Editor, former Asian Biophysics Association President, and former IUPAB President).

The format of this SI was designed around two basic foundations which involved:

(i). Descriptive Commentaries: A set of Commentaries were commissioned from key members of the BSJ. These invited articles are meant to inform about the workings of the society and describe the activities which it sponsors for the benefit of its members. The opening Commentary is a short history of the BSJ written by its current president (Harada 2020). This is followed by a pair of personal recollections, written by a junior and a senior scientist, that describe the BSJ activities from a forward and rearward facing perspective (Okamoto 2020; Kataoka 2020). Next are two Commentaries outlining the financial 
Table 1 Contributed session commentaries

\begin{tabular}{|c|c|}
\hline Session topic & Reference \\
\hline $\begin{array}{l}\text { 1SBA Integrative approaches towards understanding } \\
\text { of gene expression }\end{array}$ & Mori and Sekine 2020 \\
\hline $\begin{array}{l}\text { 1SCA Utilization of soft compartments/interfaces from } \\
\text { nano to macroscale: Exploring the potential of living systems }\end{array}$ & Sato et al. 2020 \\
\hline $\begin{array}{l}\text { 1SEA Physics of chromatin dynamics-towards understanding } \\
\text { the regulation of gene expression }\end{array}$ & Ito and Kimura 2020 \\
\hline $\begin{array}{l}\text { 1SGA Frontiers in multi-scale mechanobiology of muscle and } \\
\text { vascular system }\end{array}$ & Iwaki and Hara 2020 \\
\hline $\begin{array}{l}\text { 1SBP ASB-BSJ Joint Symposium: Current challenges in } \\
\text { biophysics centering on biomolecular interactions and the } \\
\text { underlying forces }\end{array}$ & Kvansakul and Nishizaka 2020 \\
\hline 1SCP Cutting-edge brain research from a biophysical perspective & Tominaga and Kuhn 2020 \\
\hline 1SDP Current status and issues of protein solution biophysics & Yanaka and Uchiyama 2020 \\
\hline 1SEP What is "Single-cell PRESTO" doing? & Suzuki and Shiroguchi 2020 \\
\hline $\begin{array}{l}\text { 1SHP Frontier of structure-function studies to unveil diverse } \\
\text { GPCR signaling }\end{array}$ & Katayama and Suno 2020 \\
\hline $\begin{array}{l}\text { 2SCA Challenges of bioinformatics for the era of molecular } \\
\text { structure big-data }\end{array}$ & Shirai and Terada 2020 \\
\hline $\begin{array}{l}\text { 2SDA Nonequilibrium Energetics of Biological } \\
\text { Molecular Machines }\end{array}$ & Toyabe et al. 2020 \\
\hline 2SEA Frontiers of Synchrotron Radiation Biophysics & Iwamoto and Sekiguchi 2020 \\
\hline 2SFA Elucidation of biological functions by optical control & Tsukamoto and Shichida 2020 \\
\hline $\begin{array}{l}\text { 2SBP Measure x Analyze Metabolic Adaptation of } \\
\text { Biological Systems }\end{array}$ & Okada and Bamba 2020 \\
\hline $\begin{array}{l}\text { 2SDP Taiwan-Japan joint symposium on structural biology } \\
\text { using X-ray crystallography and cryo-EM }\end{array}$ & Murata 2020 \\
\hline $\begin{array}{l}\text { 2SHP Decoding intracellular architecture using visualizing } \\
\text { device development and mathematical modeling }\end{array}$ & Kitamura and Kabayama 2020 \\
\hline $\begin{array}{l}\text { 3SBA Structure, Dynamics and Energy Flow that Govern } \\
\text { Heme Protein Functions: Theory and Experiments }\end{array}$ & Yamatoa and Leitner 2020 \\
\hline $\begin{array}{l}\text { 3SCA Diversity and universality of motile mechanism of } \\
\text { living things: From intracellular dynamics to collective motion }\end{array}$ & Nakamura and Kage 2020 \\
\hline $\begin{array}{l}\text { 3SDA Optogenetics: Applying photoreceptor for understanding } \\
\text { biological phenomena }\end{array}$ & Tsunoda and Inoue 2020 \\
\hline 3SFA Biophysics in Nano-space & Tadakuma and Kitagawa 2020 \\
\hline
\end{tabular}

position and the internet presence of the BSJ, respectively, written by the BSJ Treasurer (Akiyama 2020) and website Liaison officer (Miyata 2020). The BSJ runs two international journals - the Japanese language Seibutsu Butsuri ${ }^{3}$ and the English language Biophysics and Physicobiology - their respective Chief Editors provide very informative Commentaries describing how to both access and publish within them (Sako 2020; Ishiwata 2020). Next is a Commentary on a new government program known as the AMED BINDS initiative (promoting the use of biophysics to develop novel drugs) which provides significant insight into how the Japanese government identifies and targets specific biophysical programs for funding (Nakamura 2020). When researchers outside of Japan think about Japanese research centers, they are most likely to mention RIKEN, University of Tokyo, and Kyoto University. To round

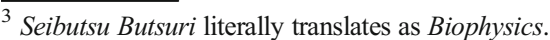

out this set of Commentaries, the SI Editors have commissioned articles describing the biophysical research performed at institutes that may be less well known to the casual observer but which are nevertheless important powerhouses of biophysical research within Japan. These include Kanazawa University (Ando 2020), Hokkaido University (Aizawa et al. 2020), Waseda University (Takano et al. 2020), Kyushu University (Akiyama et al. 2020a), and the Okazaki National Institutes of Natural Sciences (Akiyama et al. 2020b). In toto, this set of Commentaries should provide those interested in learning about biophysics in Japan with an insight into the makeup of the BSJ, along with some potentially new places and people to collaborate with and new platforms to communicate one's science.

(ii). Scientific contributions: Commissioned from speakers at the $57^{\text {th }}$ Annual Meeting of the BSJ held in Miyazaki, Japan, the scientific contributions were of two types, descriptive session commentaries and 
Table 2 Review articles commissioned by the SI editors
Review title Reference

Opto-thermal diffusiophoresis of soft biological matters: From physical principle to molecular manipulation

Fukuyama and Maeda 2020

Methods and application of coherent X-ray diffraction imaging of noncrystalline particles

Dominant rule of community effect in synchronized beating behavior of cardiomyocyte networks

Neural networks for protein structure and function prediction and dynamics analysis

Microfluidic approaches for the analysis of protein-protein interactions

Effect of additives on liquid droplets and aggregates of proteins

The challenge of intracellular temperature

Biological phase separation: cell biology meets biophysics

Role of atomic contacts in vibrational energy transfer in myoglobin

Experimental and theoretical energetics of walking molecular motors under fluctuating environments

Theoretical identification of thermostabilizing amino-acid mutations for $\mathrm{G}$ protein-coupled receptors

Heterogeneous fluid-like movements of chromatin and their implications to transcription

Novel optogenetics tool: Gt_CCR4 A light-gated cation channel with high-reactivity to weak light

Efficiencies of molecular motors: A comprehensive overview

Nonspecific characteristics of macromolecules create specific effects in living cells

Development of a deep-learning-based method to identify "good" regions of a cryo-electron microscopy grid

Recent advances in bioimaging with high-speed atomic force microscopy

Application of information theory in systems biology

Allosteric communication in molecular machines via information exchange: what can be learned from dynamical modeling

Correlation between the numbers of rotation steps in the ATPase and proton conducting domains of F- and V-ATPases

Recent progress of in-cell NMR of nucleic acids in living human cells

Recent developments in the computational study of protein structural and vibrational energy dynamics

Action of antimicrobial peptides and cell-penetrating peptides on membrane potential revealed by the single GUV method

Metabolic features of cancer cells in NRF2 addiction status

Unique phase behavior in cell size space: Synergetic effect of molecular crowding and confinement

Unexpected molecular diversity of vertebrate non-visual opsin Opn5

The biological structure model archive: An archive for in silico models and simulations

Biophysics of rhodopsins and optogenetics

Heterochromatin protein 1 (HP1): interactions with itself and chromatin components

Synchronous operation of biomolecular engines

Accurate and rapid calculation of hydration free energy and its physical implication for biomolecular functions
Nakasako et al. 2020

Tsuchiya and Tomii 2020

Arter et al. 2020

Shiraki et al. 2020

Suzuki and Plakhotnik 2020

Yoshizawa et al. 2020

Mizuno and Mizutani 2020

Ariga et al. 2020

Murata et al. 2020

Ashwin et al. 2020

Hososhima et al. 2020

Li and Toyabe 2020

Tsumoto et al. 2020

Yokoyama et al. 2020

Uchihashi and Ganser 2020

Uda 2020

Loutschko and Flechsig 2020

Noji et al. 2020

Yamaoki et al. 2020

Leitner and Yamato 2020

Moghal et al. 2020

Okazaki et al. 2020

Watanabe and Yanagisawa 2020

Yamashita 2020

Bekker et al. 2020

Kandori 2020

Kumar and Kono 2020

Keya et al. 2020

Kinoshita and Hayashi 2020
Yasuda 2020 scientific reviews. Session commentaries were requested from the chairpersons of each of the 35 scientific sessions held at the meeting (Table 1). The scientific review contributions were collectively decided upon by the SI editors after witnessing talks at the meeting, with a best effort made for inclusion of 
a representative selection of meeting topics. In all there were 31 commissioned reviews on topics that spanned the 35 scientific sessions. These review articles are shown in Table 2.

\section{Conclusions}

A constant feature of human development has been the creation of organizational structures that (ideally) help to plan and coordinate the effort of their members for the overall benefit of the collective. This Special Issue represents the confluence of three such structures-IUPAB, Biophysical Reviews, and the Biophysical Society of Japan (BSJ). The reason for this union was the commencement of a partnership program that is aimed at highlighting biophysical research within a single country and presenting it on a world stage. As the official IUPAB journal Biophysical Reviews is uniquely suited to promoting research work conducted and funded at the national level. We hope that this SI on the Biophysical Society of Japan has provided readers with a greater insight and understanding of biophysical research in Japan. We look forward to working with other national societies to further promulgate such activities.

Acknowledgments I would again like to thank Dr. Meran Lloyd-Owen for comments on an early draft of the current manuscript. I would like to acknowledge the Institute for Protein Research at Osaka University for the remarkable support they have provided to me over the last 5 years. I also gratefully acknowledge the support provided by the US Government over the last year in the way of funds for an ORISE Established Scientist Position carried out at the NIDDK. All opinions expressed in this paper are the author's and do not necessarily reflect the policies and views of NLM, DOE, or ORAU/ORISE.

Funding information This research was supported in part by an appointment to the National Library of Medicine (NLM) Research Participation Program. This program is administered by the Oak Ridge Institute for Science and Education through an interagency agreement between the US Department of Energy (DOE) and the National Library of Medicine (NLM). ORISE is managed by ORAU under DOE contract number DE-SC0014664.

\section{References}

Aizawa T, Demura M, Gohara K, Haga H, Ishimori K, Kinjo M, Komatsuzaki T, Maenaka T, Yao M (2020) Biophysical research in Hokkaido University, Japan. Biophys Rev 12(2) (Current Issue)

Akiyama S (2020) Treasurer's comments on the financial position of the Biophysical Society of Japan. Biophys Rev 12(2) (Current Issue)

Akiyama R, Annaka M, Kohda D, Kubota H, Maeda Y, Matsumori N, Mizuno D, Yoshida N (2020a) Biophysics at Kyushu University. Biophys Rev 12(2) (Current Issue)

Akiyama S, Aoki K, Kubo Y (2020b) Biophysical research in Okazaki, Japan. Biophys Rev 12(2) (Current Issue)

Ando T (2020) Biophysics in Kanazawa University. Biophys Rev 12(2) (Current Issue)
Ariga T, Tomishige M, Mizuno D (2020) Experimental and theoretical energetics of walking molecular motors under fluctuating environments. Biophys Rev 12(2) (Current Issue)

Arter WE, Levin A, Krainer G, Knowles TPJ (2020) Microfluidic approaches for the analysis of protein-protein interactions. Biophys Rev 12(2) (Current Issue)

Ashwin SS, Maeshima K, Sasai M (2020) Heterogeneous fluid-like movements of chromatin and their implications to transcription. Biophys Rev 12(2) (Current Issue)

Bekker GJ, Kawabata T, Kurisu G (2020) The biological structure model archive: an archive for in-silico models and simulations. Biophys Rev 12(2) (Current Issue)

Fukuyama T, Maeda YT (2020) Opto-thermal diffusiophoresis of soft biological matters: from physical principle to molecular manipulation. Biophys Rev 12(2) (Current Issue)

Hall D (2019) Biophysical reviews: promoting the African synchrotron facility, partnering with national biophysical societies, highlighting advances in structural biology. Biophys Rev 11(3):495-497

Harada Y (2020) Greetings from the president of the Biophysical Society of Japan. Biophys Rev 12(2) (Current Issue)

Hososhima S., Shigemura S., Kandori H. and Tsunoda S.P. (2020) Novel optogenetics tool: Gt CCR4 a light-gated cation channel with highreactivity to weak light. Biophys Rev. 12 (2) (Current Issue)

ISC (2020) https://council.science/about-us/

Ishiwata S (2020) On the on-line journal "Biophysics and Physicobiology (BPPB)". Biophysical Reviews 12 (2) (Current Issue)

Ito Y. and Kimura A. (2020) Session 1SEA - physics of chromatin dynamics 1 at the $57^{\text {th }}$ Biophysical Society of Japan meeting. Biophys Rev. 12 (2) (Current Issue)

IUPAB (2020) http://iupab.org/

Iwaki M, Hara Y (2020) Overview of the frontiers in multi-scale mechanobiology of muscle and vascular system - session 1SGA. Biophys Rev 12(2) (Current Issue)

Iwamoto H. and Sekiguchi H. (2020) Overview of "2SEA: Frontiers of Synchrotron Radiation Biophysics" session of symposia in the 57th Annual Meeting of Biophysical Society of Japan (2020) Biophys Rev. 12 (2) (Current Issue)

Kandori H (2020) Biophysics of rhodopsins and optogenetics. Biophys Rev 12(2) (Current Issue)

Kataoka M (2020) Biophysical Society of Japan, 45years ago. Biophys Rev 12(2) (Current Issue)

Katayama K, Suno R (2020) The Biophysical Society of Japan (BSJ) Miyazaki meeting, September, 2019 session 1SHP- frontier of structure-function studies to unveil diverse GPCR signaling. Biophys Rev 12(2) (Current Issue)

Keya JJ, Kabir AMR, Kakugo A (2020) Synchronous operation of biomolecular engines. Biophys Rev 12(2) (Current Issue)

Kinoshita M, Hayashi T (2020) Accurate and rapid calculation of hydration free energy and its physical implication for biomolecular functions. Biophys Rev 12(2) (Current Issue)

Kitamura A, Kabayama K (2020) Session 2SHP report - decoding intracellular architecture using visualizing device development and mathematical modelling. Biophys Rev 12(2) (Current Issue)

Komatsuzaki T, Nakamura H, Tame J, Yanaka S, Nagai T, Nagayama K (2020) Editorial for the Special Issue of Biophysical Reviews focused on the Biophysical Society of Japan with select scientific content from the $57^{\text {th }}$ BSJ annual meeting, Miyazaki, Japan. Biophysical Reviews 12(1) (Current Issue)

Kumar A, Kono H (2020) Heterochromatin protein 1 (HP1): interactions with itself and chromatin components. Biophys Rev 12(2) (Current Issue)

Kvansakul M, Nishizaka T (2020) Session 1SBP - ASB-BSJ joint symposium: current challenges in biophysics centering on biomolecular interactions and the underlying forces. Biophys Rev 12(2) (Current Issue) 
Leitner DM, Yamato T (2020) Recent developments in the computational study of protein structural and vibrational energy dynamics. Biophys Rev 12(2) (Current Issue)

Li C, Toyabe S (2020) Efficiencies of molecular motors: a comprehensive overview. Biophys Rev 12(2) (Current Issue)

Loutschko D, Flechsig H (2020) Allosteric communication in molecular machines via information exchange: what can be learned from dynamical modeling. Biophys Rev 12(2) (Current Issue)

Miyata M (2020) Current status of the website of the iophysical Society of Japan. Biophys Rev 12(2) (Current Issue)

Mizuno M, Mizutani Y (2020) Role of atomic contacts in vibrational energy transfer in myoglobin. Biophys Rev 12(2) (Current Issue)

Moghal MMR, Hossain F, Yamazaki M (2020) Action of antimicrobial peptides and cell-penetrating peptides on membrane potential revealed by the single GUV method. Biophys Rev 12(2) (Current Issue)

Mori T, Sekine S (2020) Overview of the "1SBA: integrative approaches towards understanding of gene expression" session at the 57th BPSJ meeting. Biophys Rev 12(2) (Current Issue)

Murata T (2020) Overview of Taiwan-Japan joint symposium (2SDP) on structural biology using X-ray crystallography and cryo-EM at the 2019 BSJ meeting. Biophys Rev 12(2) (Current Issue)

Murata T, Yasuda S, Hayashi T, Kinoshita M (2020) Theoretical identification of thermostabilizing amino-acid mutations for G-protein coupled receptors. Biophys Rev 12(2) (Current Issue)

Nagayama K (2020) Biophysical Reviews' "Meet the Editors Series"- a profile of Kuniaki Nagayama: encounters and leaps in a transborder journey through biophysics. Biophysical Reviews 12(2) (Current Issue)

Nakamura H (2020) Big data science at AMED-BINDS. Biophys Rev 12(2) (Current Issue)

Nakamura S. and Kage A. (2020) The 57th annual meeting of the Biophysical Society of Japan Session 3SCA - diversity and universality of motile mechanism of living things: from intracellular dynamics to collective motion. Biophys Rev. 12 (2) (Current Issue)

Nakasako M, Kobayashi A, Takayama Y, Asakura K, Oide M, Okajima K, Oroguchi T, Yamamoto M (2020) Methods and application of coherent X-ray diffraction imaging of noncrystalline particles. Biophys Rev 12(2) (Current Issue)

Noji H, Ueno H, Kobayashi R (2020) Correlation between the numbers of rotation steps in the ATPase and protonconducting domains of Fand V-ATPases. Biophys Rev 12(2) (Current Issue)

Okada M, Bamba T (2020) 2SBP: overview of the trans-omics sessionmeasure $\times$ analyze metabolic adaptation of biological systems - at the 2019 BSJ meeting in Miyazaki. Biophys Rev 12(2) (Current Issue)

Okamoto K (2020) From a young BSJ member: advanced technologies encouraged me to dive into biophysics field. Biophys Rev 12(2) (Current Issue)

Okazaki K, Papagiannakopoulos T, Motohashi H (2020) Metabolic features of cancer cells in NRF2 addiction status. Biophys Rev 12(2) (Current Issue)

Olson W.K. (2020) Biophysical Reviews' "Meet the Editors Series"-a profile of Wilma K. Olson. Biophysical Reviews 12(1):9-12

Sako Y (2020) Seibutsu Butsuri, the official Japanese journal of the Biophysical Society of Japan. Biophys Rev 12(2) (Current Issue)

Sato Y, Morita M, Suzuki Y (2020) Session 1SCA- utilizing soft compartments /interfaces for the creation of artificial biosystems. Biophys Rev 12(2) (Current Issue)

Scimago (2019) https://www.scimagojr.com/journalrank.php?category= 1304. Accessed 1 Mar 2019

Shirai T, Terada T (2020) Overview of the big data bioinformatics symposium (2SCA) at BSJ2019. Biophys Rev 12(2) (Current Issue)
Shiraki K, Mimura M, Nishinami S, Ura T (2020) Effect of additives on liquid droplets and aggregates of proteins. Biophys Rev 12(2) (Current Issue)

Suzuki M, Plakhotnik T (2020) The challenge of intracellular temperature. Biophys Rev 12(2) (Current Issue)

Suzuki M, Shiroguchi K (2020) BSJ 2019 “single-cell PRESTO” session. Biophys Rev 12(2) (Current Issue)

Tadakuma H. and Kitagawa D. (2020) Overview of the "biophysics in nano-space" session at the 57th annual meeting of the biophysical Society of Japan. Biophys Rev. 12 (2) (Current Issue)

Takano M. Yura K., Ueda T. and Yasuda K. (2020) Biophysics at Waseda. University. Biophys Rev. 12 (2) (Current Issue)

Tominaga T. and Kuhn B. (2020) Cutting-edge brain research from a biophysical perspective symposium synopsis of session 1SCP at BSJ2019 in Miyazaki, Kyushu, Japan. Biophys Rev. 12 (2) (Current Issue)

Toyabe S., Li C.B. Kinbara K. (2020) Session 2SDA | Nonequilibrium energetics of biological molecular machines Biophys Rev. 12 (2) (Current Issue)

Tsuchiya Y, Tomii K (2020) Neural networks for protein structure and function prediction and dynamics analysis. Biophys Rev 12(2) (Current Issue)

Tsukamoto H, Shichida Y (2020) Session 2SFA - the symposium "elucidation of biological functions by optical control" on BSJ2019 at Miyazaki, Japan. Biophys Rev 12(2) (Current Issue)

Tsumoto K, Sakuta H, Takiguchi K, Yoshikawa K (2020) Nonspecific characteristics of macromolecules create specific effects in living cells. Biophys Rev 12(2) (Current Issue)

Tsunoda S.P. and Inoue K. (2020) A series of commentaries for a symposium entitled "session 3SDA - optogenetics: applying photoreceptor for understanding biological phenomena". Biophys Rev. 12 (2) (Current Issue)

Uchihashi T. and Ganser C. (2020) Recent advances in bioimaging with high-speed atomic force microscopy. Biophys Rev. 12 (2) (current issue)

Uda S. (2020) Application of information theory in systems biology. Biophys Rev. 12 (2) (Current Issue)

Watanabe C. and Yanagisawa M. (2020) Unique phase behavior in cell size space: synergetic effect of molecular crowding and confinement

Yamaoki Y., Nagata T., Sakamoto T. and Katahira M. (2020) Recent progress of in-cell NMR of nucleic acids in living human cells. Biophys Rev. 12 (2) (Current Issue)

Yamashita T. (2020) Unexpected molecular diversity of vertebrate nonvisual opsin Opn5. Biophys Rev. 12 (2) (Current Issue)

Yamatoa T. and Leitner D.M. (2020) Structure, dynamics, and energy flow that govern heme protein functions: theory and experiments. Session 3SBA at the 57th BSJ annual meeting. Biophys Rev. 12 (2) (Current Issue)

Yanaka S. and Uchiyama S. (2020) Current status and issues of protein solution biophysics - session 1SDP. Biophys Rev. 12 (2) (Current Issue)

Yasuda K. (2020) Dominant rule of community effect in synchronized beating behavior of cardiomyocyte networks. Biophys Rev. 12 (2) (current issue)

Yokoyama Y., Terada T., Shimizu K., Nishikawa K., Kozai D., Shimada A., Mizoguchi A., Fujiyoshi Y. and Tani K. (2020) Development of a deep-learning-based method to identify "good" regions of a cryoelectron microscopy grid. Biophys Rev. 12 (2) (Current Issue)

Yoshizawa T., Nozawa R., Jia T.Z., Saio T. and Mori E. (2020) Biological phase separation: cell biology meets biophysics. Biophys Rev. 12 (2) (Current Issue)

Publisher's note Springer Nature remains neutral with regard to jurisdictional claims in published maps and institutional affiliations. 